\title{
UMA IDENTIDADE MUNICIPAL DESAFIADA: ANÁLISE DO CONFLITO EM TORNO DO COMÉRCIO REALIZADO POR INDÍGENAS EM UMA CIDADE DA SERRA GAÚCHA ${ }^{1}$
}

JULIANE BAZZO ${ }^{2}$

UFRGS

\begin{abstract}
RESUMO: $O$ artigo aborda o conflito em torno do comércio realizado por indígenas Kaingang em um município turístico da Serra Gaúcha, sob a luz do processo sócio-histórico de elaboração da identidade emblemática da cidade. A despeito do poder público e de outros segmentos sociais locais confrontarem as atividades mercadológicas dos indios com a justificativa de uma necessária regulação comercial, advoga-se aqui que o embate encontra explicação mais profunda no choque que estabelece com uma identidade citadina representativa, centrada na ideia de uma mescla étnica bem-sucedida, propiciada pela colonização alemã e italiana. O abalo identitário ocorre não apenas pela presença dos indígenas na cidade, mas também pela forma de comércio por eles realizada, classificada enquanto ambulante, bem como pelo tipo de produto vendido, caracterizado como industrializado de origem asiática. A partir dessa discussão central, outros contrastes identitários históricos elou contemporâneos são problematizados.
\end{abstract}

PALAVRAS-CHAVE: antropologia urbana; indígenas em cidades; conflitos espaciais.

ABSTRACT: The article approaches the conflict over the commerce carried out by the Kaingang people in a tourist town located in the Gaucho Highlands, southern Brazil, under the light of the socio-historical process of elaboration of the city's iconic identity. Despite the government and other local social segments opposing to their marketing activities, with the justification of a required commercial regulation, it is advocated here that the dispute has a deeper explanation -- the shock with the town's representative identity, which is centered in the idea of a successful ethnic blend, provided by the German and Italian colonization. This shock occurs not only by the presence of the indians in the city, but also by the $w$ of trade undertaken by them, classified as itinerant, as well as by the type of product sold, characterized as industrialized and made in Asia. From this central discussion, other historical and/or contemporary identity contrasts are discussed.

KEYWORDS: urban anthropology; indians in cities; spatial conflicts.

\footnotetext{
1 Agradeço a Cornelia Eckert e a Ana Luiza Carvalho da Rocha pelas valiosas interlocuções para a elaboração deste artigo, no âmbito do curso Antropologia Urbana e Etnografia nas Sociedades Complexas, ministrado no PPGAS/UFRGS. Também sou grata ao etnólogo Alexandre Aquino pelas indicações bibliográficas especializadas, bem como pelos contatos abertos para conversas com os indígenas protagonistas deste artigo, os quais são também sujeitos de pesquisa do estudioso entre os Kaingang no Rio Grande do Sul.

${ }^{2}$ Doutoranda do Programa de Pós-Graduação em Antropologia Social (PPGAS) da Universidade Federal do Rio Grande do Sul (UFRGS). E-mail: bazzojuliane@gmail.com.
} 


\section{Introdução}

A Serra Gaúcha tornou-se há dois anos meu local de moradia e, no processo de virar residente, vivenciei uma dupla experiência: nos termos de Velho (2013 [1978]), familiarizei-me com o estranho, posto não ser minha região de origem e, simultaneamente, estranhei 0 familiar, dado o ofício de antropóloga ${ }^{3}$. Esse autor afirma que "momentos de descontinuidade" nas sociedades complexas contemporâneas, como os conflitos, por exemplo, possuem valor ímpar na qualificação do "processo de estranhar o familiar". Em tais períodos, coletividades "desviantes", ao subverter a ordenação do dia a dia, tornam manifestas diferenças culturais, bem como divergências ideológicas e de interesses. Foi em uma dessas ocasiões que surgiu a motivação para este artigo.

Em novembro de 2013, fazia eu a leitura cotidiana de um dos principais jornais do município que chamarei pelo nome fictício de Viçoso, conhecido destino de turismo da Serra Gaúcha, quando me deparei com a seguinte pergunta: $O$ que é pior: índios ou o lixo pela

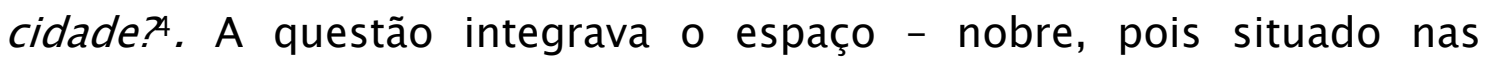
páginas iniciais da publicação - reservado a um colunista, cujo costume é encerrar sua série bissemanal de notas noticiosas com uma interrogação provocativa ao leitor.

A citada pergunta referia-se a dois assuntos que à época geravam polêmica: a precariedade da coleta de lixo, posteriormente transferida das mãos do poder público para uma empresa privada e o comércio realizado por indígenas da etnia Kaingang, que haviam estabelecido um camelódromo, não autorizado pela prefeitura municipal, no corredor de entrada de um destacado parque turístico local.

\footnotetext{
${ }^{3}$ A transferência se deu a partir do Estado do Paraná, de onde sou natural, em virtude de motivações a um só tempo familiares e profissionais.

${ }^{4} \mathrm{O}$ emprego de um nome municipal fictício encontra inspiração, por exemplo, em Elias e Scotson (2000), que analisam tensas relações sociais entre "estabelecidos" e "outsiders" em uma pequena cidade inglesa que os autores denominam por Winston Parva.
} 
$\mathrm{Na}$ edição subsequente do jornal, em virtude do recebimento de críticas de leitores quanto à questão antes colocada, o colunista desculpou-se com aqueles que "Ihe entenderam mal" e insistiu em refazer a interrogação, de forma a evidenciar suas intenções que, segundo ele, objetivavam a promoção do debate comunitário. No fecho da coluna, então, novamente perguntou: Qual problema é o mais urgente: o recolhimento de lixo ou a ocupação irregular [do parque]?

Conforme assinala Bohrer (2011, p. 130), ainda que o conteúdo jornalístico não reflita de maneira especular a opinião da totalidade de um contingente populacional, esse gênero de material constitui “... um aporte documental importante para trabalhar diferentes visões sobre os valores e preceitos da realidade social"5. A partir desta e de outras espécies de registros, este artigo discute o conflito em torno do comércio realizado por indígenas em Viçoso, no período entre 2006 e 2014, sob a luz do processo sócio-histórico de elaboração da identidade representativa da cidade $^{6}$.

O conceito de identidade abraçado é o de Oliven (2011), que compreende tal noção como uma "construção social" mobilizada por intermédio de "diferenças reais ou inventadas", capazes de conferir uma "marca de distinção", de maneira a contrastar com outras identidades. Nesse âmbito, pronuncia-se analiticamente aqui a feição "emblemática" da identidade de Viçoso, ou seja, aquela que, segundo assinala Duarte (1988), abrange a percepção do senso comum dominante. Em tal sentido, costumeiramente, a sociedade é entendida como "justaposição linear de grupos" e a cultura delimitada como "somatório de traços ou elementos", como na ótica durkheimiana.

A despeito de a prefeitura, do empresariado municipal e da população local confrontarem publicamente as atividades mercadológicas dos indígenas sob justificativa de uma necessária regulação do comércio citadino, advoga-se que o conteúdo e a

\footnotetext{
${ }^{5}$ A observação do autor integra uma análise antropológica sobre a "invisibilidade" de territórios negros urbanos na cidade de Porto Alegre (RS) no período pós-abolição. Na feitura desse trabalho, Bohrer lança mão de uma série de relatos noticiosos.

${ }^{6}$ Importa destacar, portanto, que a presente reflexão, embora considere contribuições da literatura em etnologia indígena, ampara-se prioritariamente no arcabouço conceitual da antropologia urbana. Por conseguinte, diferentemente do que fez, por exemplo, Gordon (2006) entre os Xikrin, não se pretende analisar o status que ocupam na cosmologia dos Kaingang os artigos tradicionais ou industrializados por eles vendidos na cidade em questão.
} 
magnitude adquiridos por esse embate encontram explicação de ordem mais profunda. Tal explicação reside no choque que o conflito estabelece com a identidade emblemática de Viçoso, fundamentada na história da imigração alemã e italiana ao município, centrada na atividade turística e fortalecida por políticas públicas e empresariais.

Nesse sentido, o abalo identitário ocorre não apenas pela presença dos indígenas na cidade, mas também pela forma de comércio por eles realizada, classificada enquanto ambulante, bem como pelo tipo de produto que comercializam, caracterizado como industrializado de origem asiática, aspectos estes que serão debatidos na sequência.

Para a implementação da análise, além de literatura antropológica e histórica, houve o emprego de dados de diversas naturezas: de conteúdo noticioso dos dois principais jornais impressos locais ${ }^{7}$ e de sites da internet; de documentação oficial relativa ao conflito arquivada na prefeitura; bem como de incursões etnográficas ao camelódromo no parque turístico, para interlocuções com os indígenas e acompanhamento da movimentação de visitantes. Tais idas a campo aconteceram especialmente durante o período da Copa do Mundo de Futebol 2014, quando Viçoso recebeu um bom volume de turistas.

Ademais, a reflexão compreende a "observação flutuante" (PÉTONNET, 2008) por mim realizada ao longo da vivência na região onde se situa Viçoso. Segundo essa autora, tal método etnográfico propõe que a atenção do antropólogo vagueie pela cidade durante os percursos e as atividades dele enquanto citadino e, ao mesmo tempo, fique "disponível em toda circunstância", "...de modo que as informações o penetrem sem filtro, sem a priori, até o momento em que pontos de referência, de convergências, apareçam e nós che[guemos], então, a descobrir as regras subjacentes" (PÉTONNET, 2008, p. 102).

\section{A utopia europeia}

A história oficializada de Viçoso tem enquanto marco a chegada, no século XIX, de imigrantes alemães e italianos que, uma vez

\footnotetext{
${ }^{7}$ É preciso apontar que o poder público do município realiza propaganda oficial em ambos os veículos e, desse modo, considerar possíveis efeitos disso sobre a cobertura jornalística.
} 
estabelecidos no território ainda sem autonomia municipal, trabalharam a terra, obtiveram a propriedade dela, prosperaram economicamente e, desse modo, exerceram influência determinante para a concretização da cidade. Localmente, entende-se que a colonização alemã e italiana propiciou uma satisfatória mescla cultural, que legou aos viçosenses hábitos gastronômicos, um estilo arquitetônico, o apreço pelo trabalho, a vocação para o empreendedorismo, o conhecimento para enfrentar o frio rigoroso, dispositivos morais, enfim, todo um ethos de caráter europeu.

Desse modo, é a eficácia dessa "mistura" - expressão comum em falas nativas - que, sob a ótica local, opera como pano de fundo dos índices positivos alcançados pelo município na atualidade. Dentre eles, por exemplo, o status de Viçoso entre os destinos turísticos mais procurado pelos brasileiros (MINISTÉRIO DO TURISMO, 2012) ou a posição da cidade na faixa de desenvolvimento humano alto na análise desse quesito entre as cidades do país (PNUD, 2013).

Tal retrato encontra-se transposto em livros sobre o passado e o presente de Viçoso e, neles, não raro é apresentado com o uso de um estilo textual peculiar, de características jactanciosa e megalômana, que desperta atenção antropológica. A seguir, reproduzo alguns trechos assinados por indivíduos oriundos de diferentes segmentos socioprofissionais 8 :

[A] marca distintiva [de Viçoso] é o trabalho criativo e persistente. $O$ excelente clima de altitude, o laborioso capricho de seus habitantes, a arquitetura de suas moradas ao estilo europeu transformaram [Viçoso] num grande polo de atração turística. (...) O dinamismo de seu povo e seus administradores impeliu o município a ocupar espaço de relevo nas áreas da cultura, lazer e recreação, que o vem consagrando nacional e internacionalmente (Deputado Estadual).

Com sólidos alicerces culturais a cidade de [Viçoso] desponta como uma eterna primavera, onde 0 despertar da sua flora e da sua natureza humana estão em constante e ininterrupto florescimento (Professora Municipal).

\footnotetext{
${ }^{8}$ Os excertos foram pinçados de fontes de consulta histórica disponíveis na biblioteca municipal.
} 
Não há desemprego nem favelas. Enfim, o esplendor (...) e, com ele, as delícias do apogeu (Professor Universitário).

Por conseguinte, para se caracterizar hoje como europeizada, a identidade emblemática de Viçoso alicerça-se em uma narrativa fundacional que foca na contribuição alemã e italiana em detrimento de outras etnias, inclusa a indígena, que também são portadoras de uma história nessa região, como se exporá adiante. Logo, a identidade representativa do município baseia-se em uma "história-mito", para usar uma noção de Godoi (1998) que considera história e mito em pé de igualdade, num relato no qual importa menos a veracidade e mais a eficiência para quem o detém.

A "história-mito" constitui um gênero narrativo revelador de que acontecimentos históricos não têm sentido em si mesmos: a acepção deles, como nos mitos, é construída com aquilo que se mostra significativo para ação num dado arcabouço cultural. Godoi (1998), em trabalho etnográfico entre camponeses do Piauí, verificou a ausência de uma evidente ascendência indígena nas genealogias. Segundo ela, tal relato de origem excluía os índios por atuar enquanto "armadura sociológica" de respaldo dos direitos campesinos sobre seu território.

Nesse sentido, Almeida (2006) registrou justamente o contrário, em laudo antropológico acerca do deslocamento compulsório de grupos quilombolas, para implantação da Base de Lançamento de Foguetes de Alcântara, no Maranhão. Os afrodescendentes por ele entrevistados não desvinculavam negros e índios nas relações de parentesco, dado que a precedência destes últimos legitimava a conexão dos primeiros com o território em disputa.

Nota-se, portanto, o registro na literatura antropológica de uma série de gradações locais na famosa "fábula" da mistura exitosa das três raças no Brasil - índia, branca (notadamente portuguesa) e negra, analisada por DaMatta (1990). Contudo, a despeito de tais variações se revelarem comuns, é preciso não colocá-las todas sob uma mesma categoria, tendo em vista que expressam relações de poder desiguais.

Assim, narrativas fundacionais abraçadas por camponeses ou quilombolas e empregadas em suas reivindicações enquanto "minorias" nacionais têm, indubitavelmente, panos de fundo, significados e 
consequências muito diversas de uma "história-mito" (GODOI, 1998) propagada por uma população parte de uma "maioria", em posição privilegiada no status quo brasileiro de profundas diferenças socioeconômicas. Esta última situação, como se verificará, configura o caso da cidade protagonista deste artigo.

\section{Em busca de blindagem identitária}

Em sua trajetória defensiva, a identidade emblemática de Viçoso tem sido expressa numa cidade cuja estrutura se aproxima do "enclave fortificado", noção esta de Caldeira (2000), empregada numa pesquisa antropológica sobre o estabelecimento de condomínios fechados em meio ao avanço da criminalidade paulistana. Segundo a autora, os enclaves fortificados comportam traços distintivos, que permitem comparações a despeito de diferenças estruturais entre eles.

Dentre tais aspectos, interessam os seguintes para o caso em análise aqui: (1) a ênfase ao privado e ao restritivo em detrimento do que é público e disponível no espaço citadino; (2) a aspiração de criar "ambientes socialmente homogêneos", compostos por indivíduos selecionados, afastados de "interações indesejadas", da diversidade, das contingências e da insegurança dos contextos urbanos; (3) a busca pela conferência de "status" a seus usuários, residentes e turistas, pela via da "afirmação de distância e [de] desigualdades sociais"; (4) o estabelecimento de um relacionamento paradoxal de "dependência e evitação" com segmentos mais empobrecidos da população, tendo em vista que estes permanecem sendo a mão de obra que faz a cidade funcionar.

Caldeira (2000) verifica que a dispersão dos enclaves fortificados em São Paulo coincide com o período da redemocratização brasileira. Tal constatação permite a ela postular que os ordenamentos urbanos não necessariamente ocorrem em consonância com os arranjos políticos. Segundo a autora, quanto mais os moldes políticos indicam se voltar à ampliação da cidadania, maior demonstra ser a contestação do "ideal moderno democrático de espaço público".

Essa contestação, que fique claro, não corresponde àquela 
encabeçada por movimentos sociais que expõem as moléstias das cidades contemporâneas, inclusive no que tange ao desrespeito à diversidade. Tal negação refere-se, sim, à delimitação de espaços urbanos que abraçam a "desigualdade e a separação como valores estruturantes". Enclaves fortificados, por conseguinte, não expressam meras diferenças, mas distinções compreendidas como inconciliáveis na vida urbana. Acredita-se que, por meio do estabelecimento deles, conflitos serão evitados; todavia, apenas se intensificam (CALDEIRA, 2000).

Em análise do processo de gentrificação ocorrido no Bairro do Recife (PE), Leite (2006) polemiza em torno do referido ideário urbano moderno, ao afirmar como simplista a crença em uma cidade que contempla, abertamente, todo e qualquer uso. Os ambientes citadinos resultam de intervenções "geopolíticas" permanentes, que abrangem sucessivas disputas e articulações espaciais, levadas a termo por diversos grupos sociais, com diferentes visões e interesses. Trata-se de um cenário inerente à complexidade das sociedades contemporâneas. Entretanto, desarrazoado nesse panorama é que o Estado, enquanto instância pública e regulatória, chancele empreendimentos que "realçam privilégios", em vez de promoverem a "equidade dos usos do espaço", ou seja, que o poder público atue em direção contrária à sua atribuição.

Dessa forma, com o respaldo estatal, assiste-se ao crescimento, conforme observa Leite (2006), de intervenções e caracterizações urbanas que posicionam a "cidade como empresa" e a "cultura na perspectiva dos resultados econômicos". Todavia, a despeito de seu poderio, não raro escapa a inciativas desse gênero o controle pleno sobre as utilizações e configurações citadinas. Na contramão de tais projetos, emergem "usos dissonantes dos espaços", considerados "desordens" sob o ponto de vista dominante, mas que em verdade evidenciam "formas singulares de apropriação cotidiana" do território urbano. É o que se verifica em Viçoso em relação ao comércio efetuado pelos Kaingang no município, conflito objeto de análise principal neste artigo.

Este e os outros embates que aqui serão apontados sinalizam como apropriados para Viçoso alertas que não são nenhuma novidade urbanística, mas sim constatações de pensadores clássicos das cidades. 
Lefebvre (2001 [1968], p. 22) postula que a existência do ambiente citadino está intrinsecamente conectada ao seu "valor de uso", que abrange "... encontros, confrontos das diferenças, conhecimentos e reconhecimentos recíprocos dos modos de viver". Uma cidade, portanto, que se concebe estritamente enquanto um "produto de consumo", ou seja, prioriza o "valor de troca", inexoravelmente encontrará uma série de impeditivos para manter feições saudáveis.

Uma municipalidade trabalhada para ser essencialmente consumida, em vez de usada, desliga a funcionalidade da aparência, quesitos que, conforme assinala Jacobs (2001 [1961]), precisam estar necessariamente conectados em prol da operacionalidade urbana. Afirma ela: "É tolice planejar a aparência de uma cidade sem saber que tipo de ordem inata e funcional ela possui. Encarar a aparência como objetivo primordial ou como preocupação central não leva a nada, a não ser a problemas" (p. 14). Segundo a autora, cidades são ambientes de diversidade e planificações urbanas somente serão mais exitosas na medida em que ofertem "sustentação complexa, mútua e constante", de ordem social e econômica, às alteridades em meio à espacialidade urbana. Ou seja, há que se estabelecer "relações funcionais densas" nesse contexto, o que significa ir além das aparências.

\section{Percursos indígenas pela cidade}

Os Kaingang que realizam comércio em Viçoso, embora residam hoje em áreas indígenas situadas em outras localidades gaúchas, não estão por acaso na cidade objeto deste artigo. Eles ressaltam, seja em negociações com o poder público, seja nas poucas ocasiões cuja voz deles é ouvida pela imprensa local, que a região onde se localiza o município situa-se, historicamente, como um território indígena, onde existiam diversas aldeias antes da chegada dos colonizadores.

De fato, resultados de pesquisas arqueológicas disponíveis em fonte histórica oficial apontam que Viçoso foi construída por sobre uma verdadeira "Kaigangópolis" 9. Tal pertença a terra, segundo os Kaingang,

\footnotetext{
${ }^{9}$ Esta e outras fontes históricas locais a seguir mencionadas, entendidas como oficiais, integram o acervo da biblioteca municipal, amplamente consultado para a elaboração deste artigo.
} 
confere-lhes, portanto, o direito legítimo não apenas de realizar atividades comerciais na cidade, mas de efetuá-las em lugares e com produtos que atraiam os turistas.

Conforme expõe Souza (1994), os índios são figuras centrais em escritos datados de meados do século XVII, de autoria dos primeiros colonizadores do território onde mais tarde veio a ser fundado o município de Viçoso. Esses colonos pioneiros, de origem portuguesa, se instalaram em locais situados em torno de aldeias indígenas, as quais se encontravam no interior das florestas existentes. Tal ordenamento geográfico foi responsável por amenizar, embora não tenha impedido, conflitos entre os dois grupos. Os alemães, por sua vez, cuja chegada ocorreu no início do século XIX, tiveram que se estabelecer mata adentro em virtude de limitações territoriais, de modo que o corpo a corpo com os indígenas tornou-se inevitável.

Em tal contexto, configurou-se uma sangrenta guerra. Muitos colonos morreram na empreitada indígena de defender seus territórios. Os índios, contudo, vivenciaram um verdadeiro extermínio, dado o poderio de fogo das chamadas "Tropas de Bugreiros", financiadas por particulares e cujo pagamento se dava mediante a apresentação de pares de orelhas dos mortos (SOUZA, 1994).

A primeira etnia dizimada foi a Xokleng, que hoje conta com poucos representantes residentes no Estado de Santa Catarina. Os Kaingang, por sua vez, conseguiram sobreviver em maior número, pois enfrentaram ondas de colonização posteriores. Em finais do século XIX, quando os imigrantes italianos chegaram à região, os embates já tinham bruscamente diminuído, posto que muitos dos índios não mortos haviam fugido da área (SOUZA, 1994).

Nesse processo, que não ficou restrito ao território de Viçoso, mas atingiu amplamente o Estado do Rio Grande do Sul, houve indígenas que, subjugados, tornaram-se agregados dos colonos. Foram responsáveis por lhes ensinar a agricultura de coivara, o cultivo de uma série de alimentos (como a mandioca, o milho e o feijão), além de outros preciosos saberes acerca da natureza local. Ou seja, tiveram importância fundamental para que os europeus conseguissem sobreviver no novo território (SOUZA, 1994).

O romance $A$ Ferro e Fogo - Tempo de Solidão (v. 1), de autoria 
do gaúcho Josué Guimarães (1977), uma ficção pautada em extensa pesquisa histórica do autor, oferta bons subsídios para visualizar que a bem-sucedida trajetória dos imigrantes alemães envolveu muito do esforço deles, mas sem dúvida esteve intrinsecamente conjugada ao trabalho e ao conhecimento de índios e também de negros trazidos da África como escravos. Entretanto, os méritos da prosperidade alcançada aparecem historicamente conectados aos europeus, tendo em vista que eles, ao contrário das demais etnias, articularam-se ao ideal de nação aspirado para o Brasil, o qual incluía elementos como o branqueamento e a sedentarização populacional.

Como observa Souza (1994), qualquer empreitada civilizatória possui como marca o etnocentrismo. A colonização europeia nas Américas, entretanto, teve por diferencial a presença de um componente "etnocida", o qual, mais que confrontar a alteridade, pautou-se pela eliminação do "outro". Por conseguinte, o que hoje se chama Serra Gaúcha constituiu-se sobre "substrato cultural e populacional indígena", mas tal evidência está clara a apenas um restrito grupo de estudiosos. Afirma o autor:

Ao mesmo tempo em que houve o extermínio indígena para a construção de uma sociedade que se quer cópia fiel da Europa, não se consegue reconhecer que tal progresso ocorreu através da violência e do genocídio. Há, portanto, uma espécie de velamento, de negação simbólica desses acontecimentos traumáticos (SOUZA, 1994, p. 221).

É sob a luz destas e de outras questões até agora problematizadas que se faz necessário refletir sobre a constituição de Viçoso enquanto município e a feição que adquire o conflito diante da presença urbana dos Kaingang. Logo, como afirma Holston (1993), inexistem cidades "espontâneas": mesmo que não tenham sido objeto de um planejamento formalizado, todas são "pensadas" e possuem uma "lógica" perpassada por intenções políticas e ideológicas hegemônicas, quando do momento de sua concepção material.

Com isso em mente, analisar-se-á a seguir a trajetória contemporânea dos Kaingang em Viçoso para a realização de atividades comerciais. Tal percurso abrangerá a atuação indígena em três locais 
destacados do município ${ }^{10}$. Esses lugares operam, para usar um termo de Low (2000), como "microgeografias" com o potencial de expor a construção de significados em torno dos espaços citadinos, a qual se dá por meio de concepções político-ideológicas, de intervenções de design urbano e de práticas sociais.

Nesse panorama, como observa Certeau (1998), a "linguagem" dominante "se urbaniza". Todavia, sendo impossível configurar-se como uma totalidade de "operações programadas e controladas", a cidade torna-se palco recorrente da emergência de "movimentos contraditórios", que agem em oposição a poderes do tipo "panóptico".

\section{Primeira parada: uma praça aos imigrantes}

A negociação formal inaugural entre a Prefeitura de Viçoso e os Kaingang data de 2006, quando houve a assinatura de um acordo para a comercialização de artesanato indígena. Esse documento tinha por objetivo regular as vendas até então efetuadas pelos Kaingang de forma itinerante pela cidade, durante eventos de grande atração turística. Para tanto, pautou-se pelo código de posturas do município, legislação segundo a qual cabe ao poder público a organização do comércio de rua, cuja autorização considera requisitos como a localização dos pontos de venda e os tipos de produtos ofertados.

No citado acordo, a prefeitura ofereceu aos indígenas, por tempo indeterminado e de forma gratuita, porém cancelável a qualquer tempo, um estande numa feira de artesanato local, situada numa praça da cidade. $\mathrm{O}$ uso do espaço se daria, segundo o acordo, mediante a venda exclusiva de artesanato indígena, a satisfatória apresentação do ambiente e o bom atendimento aos turistas. Ademais, o documento determinava que apenas crianças com idade superior a 10 anos poderiam acompanhar os pais na comercialização.

Como motivo de rescisão expressamente citado no acordo estava um comportamento reprovado pelas autoridades quando do comércio ambulante: o pedido de esmolas a passantes por parte de crianças e

\footnotetext{
${ }^{10}$ A descrição do referido itinerário será baseada em conteúdo midiático e em documentação oficial, assim como em minhas observações e interlocuções.
} 
adolescentes indígenas. Por fim, o acordo estabelecia o compromisso dos Kaingang em alugar residências para permanência em Viçoso durante as atividades comerciais, de forma que não se instalassem precariamente pelas ruas, como então se verificava.

Todavia, ata de um encontro de negociação realizado no ano de 2007 evidencia que tal acordo não surtiu os efeitos desejados ${ }^{11}$. Nesse momento, os indígenas já comerciavam em outro lugar, a principal praça citadina, ainda mais central e de maior movimento turístico. No citado documento, eles queixam-se da insuficiência de espaço na feira de artesanato para acomodar todas as famílias kaingang que vinham a Viçoso.

Além disso, alegavam sentirem-se discriminados pelo impedimento de permanecer com suas crianças durante o período de trabalho, dado tal proibição ir contra o costume indígena de estar sempre em família. Como resultado dos debates dessa reunião, o poder público ofereceu uma área ampliada na mencionada feira de artesanato e sugeriu que os Kaingang se organizassem entre eles, lançando mão de rodízios, por exemplo.

Tal oferta não encontrou aceitação plena em meio aos indígenas: a documentação oficial dá conta da cessão do referido espaço em eventos turísticos entre 2008 e 2011, porém, nesse intervalo, os Kaingang continuaram a visualizar a praça principal como uma área propícia às vendas, não apenas de artesanato, mas de adereços industrializados.

O ano de 2012, por seu turno, registrou um acontecimento merecedor de registro: a praça onde se situava a feira de artesanato, após um processo de remodelação, foi remodelada e reinaugurada numa homenagem aos imigrantes europeus entendidos como fundadores do município. Nesse ínterim, a feira de artesanato acabou deslocada para uma área mais ao interior da cidade.

O novo visual da praça conferiu assim destaque a elementos arquitetônicos considerados como tipicamente alemães e italianos. Um dos serviços atualmente disponíveis nesse espaço reside nos roteiros de

\footnotetext{
${ }^{11}$ Este e outros encontros, que seguiram ocorrendo até o ano de 2013, em geral reuniram representantes da prefeitura municipal, do Ministério Público Federal, da Fundação Nacional do Índio (Funai-RS) e dos indígenas.
} 
turismo rural, que se propõem a apresentar aos viajantes a influência alemã e italiana na região, por meio de um passeio histórico, cultural e gastronômico à zona agropecuária municipal, onde vivem descendentes dos colonizadores.

\section{Segunda parada: praça principal}

A praça principal de Viçoso é um dos pontos turísticos situados na avenida mais importante da cidade, que funciona como uma espécie de shopping. A avenida reúne uma série de butiques, cafés, restaurantes, galerias, dentre outros estabelecimentos comerciais, em prédios de estilização germânica. Se o cenário da praça em homenagem aos imigrantes, antes referida, remete hoje ao passado colonial, a praça principal insere-se num ambiente de contemporaneidade, mas no qual se procura destacar, igualmente, um toque europeu.

A praça principal, concebida portanto como espaço fundamental da urbanidade viçosense, possuía um coreto, que passou a ser utilizado pelos Kaingang como ponto de vendas. A prefeitura, por sua vez, opôsse com veemência ao uso dessa área para fins comerciais, sob a justificativa de se destinar a apresentações culturais. Todavia, em 2012, deu-se o fechamento do coreto e a instalação ali de uma loja especializada em souvenires de um grande evento turístico, capitaneado pelo poder público por alguns meses do ano.

Tal quadro desencadeou um conflito com a comunidade local. Em 2013, um grupo de ativistas culturais organizou um abaixo-assinado para exigir da prefeitura o retorno do coreto ao seu estado anterior, para que pudesse atuar enquanto palco das manifestações artísticas da cidade. Na visão do grupo, tratava-se de um espaço lúdico e público, que erroneamente havia sido fadado a uso comercial.

Houve sinalização estatal de avaliar a reivindicação, mas o que ocorreu de fato foi a ampliação do ambiente comercial, mediante o lançamento de uma marca da cidade, o que passou a propiciar a comercialização de novos produtos, durante os demais eventos representativos locais. 


\section{Terceira Parada: um parque turístico}

Nos anos 50, uma diminuta represa artificial existente em Viçoso foi ampliada e circundada por diversas espécies vegetais na busca por criar uma paisagem europeia, intervenção esta que transformou esse lugar em um dos principais parques turísticos atuais da cidade. Além de se configurar como ambiente recreativo e de apreciação, o parque abriga hoje um espaço destinado à exposição e à venda de produtos de artistas locais. Próxima do parque também está localizada uma feira permanente de artesanato da cidade.

Em virtude do grande movimento de público nessa área, consta em documentação oficial que, entre 2011 e 2012, a prefeitura começou a disponibilizar, nos grandes eventos municipais, estrutura para que os Kaingang comercializassem no parque turístico. A ideia era complementar os espaços ofertados na antiga feira de artesanato, os quais vinham se revelando insuficientes para todas as famílias indígenas e, concomitantemente, tentar esvaziar o coreto da praça principal.

Não obstante, em 2013, os Kaingang começaram a realizar atividades comerciais permanentes no parque turístico, momento em que o confronto com o poder público e com a comunidade local recrudesceu de forma sem precedentes. Para tanto, as famílias indígenas efetuaram o aluguel de casas com o fim de efetuar estadias de maior prazo no município.

Primeiramente, os Kaingang instalaram, no corredor de entrada do parque, barracas de tapume para a venda de produtos industrializados, as quais foram removidas numa ação noturna até hoje sem autoria conhecida. Diante disso, optaram por se organizar no formato de um camelódromo, lançando mão de estruturas de mais facilitado desmonte e transporte.

Em cerca de dez barracas, eles passaram a vender especialmente adereços de inverno, como cachecóis, xales, luvas, toucas, chapéus, dentre outros similares àqueles disponíveis em lojas do centro da cidade. $O$ artesanato indígena, por sua vez, não marcava presença significativa. Os Kaingang explicavam a inviabilidade de produzi-lo em escala suficiente para venda em virtude de restrições territoriais e 
naturais das áreas onde residem, bem como afirmavam que o retorno financeiro do artesanato não lhes era suficiente para sobrevivência. Os artigos industrializados, por seu turno, despertavam maior interesse dos consumidores.

De fato, nas incursões etnográficas ao parque turístico, verifiquei que o camelódromo mobilizava expressivo público, que olhava, experimentava e pechinchava mercadorias. Impossível deixar de rememorar o que ouvi logo na chegada do primeiro dia de observações: Moça, você tem máquina de cartão? Foi a pergunta feita a uma indígena por uma turista muito interessada em comprar um de seus xales.

A aquisição dos produtos comercializados pelos indígenas se dava em cidades como Porto Alegre, São Paulo e também no Uruguai. Os Kaingang afirmavam cumprir todas as obrigatoriedades fiscais de tais transações, algo colocado em questionamento pela opinião pública local.

Nesse contexto, as reuniões entre autoridades e indígenas se intensificaram, incluindo também membros da comunidade afetados pela contenda, como representantes dos artistas locais, ocupantes de um já mencionado espaço cultural no interior do parque. Dado serem naturais do município, os artistas defenderam a prerrogativa de usufruir do movimento comercial no referido espaço, ou seja, alegaram injusta concorrência por parte dos Kaingang.

Nas atas de tais encontros, perante as autoridades de âmbito federal, tanto indígenas quanto a prefeitura teciam as mesmas queixas, porém, cada lado da disputa as situava no campo de suas próprias reivindicações: ambos afirmavam que os acordos realizados não foram cumpridos a contento, materializando o deslocamento constante dos Kaingang pela cidade.

$\mathrm{Na}$ tentativa de chegar a um consenso, a prefeitura apresentou o projeto de uma espécie de feira reservada à cultura indígena, que seria construída pelo poder público nas proximidades do parque turístico, mas com o fim exclusivo de abrigar ordenadamente a venda de artesanato kaingang. Os indígenas, por seu turno, não aceitaram a proposta, seja pelo tipo restrito de produto, seja pela localização do espaço, segundo eles, de visibilidade reduzida.

Se, por um lado, a área ofertada pelo município encontrava-se, de 
fato, no entorno do parque turístico, por outro, há que se considerar os espaços reservados aos artistas e aos artesãos locais: embora adjacentes ao parque, atraíam número bem inferior de visitantes em comparação ao camelódromo, posto que este se situava no corredor de entrada, por onde passam necessariamente todos os visitantes.

Os Kaingang sugeriram a construção da feira destinada aos indígenas na referida entrada do parque, onde pudessem continuar a comercializar os produtos de retorno comercial. Destas conversações, porém, nenhum entendimento surgiu. A prefeitura então solicitou à Justiça, no final de 2013, a reintegração de posse da área ocupada pelo camelódromo no parque turístico.

Brevemente, o poder municipal obteve liminar favorável, mas a Brigada Militar negou-se a levá-la a termo, pelo fato de o conflito envolver grupos indígenas sob proteção de legislação específica ${ }^{12}$. Ao ser comunicada disso, a Justiça local alegou não ter sido informada da condição indígena dos comerciantes no pedido de reintegração de posse e, em consequência, solicitou amparo da esfera federal para encaminhamento do processo.

Além do pedido de reintegração, no mesmo período, a prefeitura e o empresariado viçosense articularam-se para mover uma ação civil pública, em solicitação de providências de órgãos federais competentes quanto ao comércio kaingang entendido como irregular. Chegaram a providenciar um abaixo-assinado e demais documentos, no entanto, conforme anúncio da procuradoria do município, não houve andamento da iniciativa em virtude da indefinição, ainda presente naquele momento, quanto à instância jurídica responsável pelo andamento do processo, se local ou federal.

No segundo semestre de 2014, ainda antes do resultado do processo judicial encaminhado, a comunidade viçosense mobilizou-se em torno de uma manifestação pública pela retomada do parque turístico pelo governo municipal. $O$ engajamento iniciou com a criação de uma página do acontecimento numa rede social virtual.

Dadas as possibilidades de comentários livres nesse espaço da internet, logo começaram a surgir colocações de tom preconceituoso e agressivo dirigidas aos Kaingang. Isso levou os organizadores a,

${ }^{12}$ Estatuto do Índio (Lei n. 6.001/73) e Constituição Federal de 1988 (Capítulo VIII - Dos Índios). 
publicamente, reforçarem o caráter pacífico do evento e a enfatizarem que o protesto não era contra os indígenas, mas a favor do parque como ponto turístico liberto do comércio ambulante.

Como forma de despertar a atenção das autoridades e da mídia para o evento, os organizadores propuseram que, vestidos de preto e munidos de cartazes reclamatórios, os participantes efetuassem uma corrente humana em torno do parque, perfazendo a ideia de um "abraço". Houve o acionamento da Brigada Militar para realizar a segurança da manifestação, bem como da imprensa local, para a cobertura midiática.

Contudo, o protesto, agendado para um domingo, foi adiado por duas semanas consecutivas. Numa dessas oportunidades, os organizadores justificaram a transferência na página da rede social como devida a uma reunião que aconteceria entre eles e lideranças kaingang, as quais desejavam posicionar-se frente à mobilização popular.

Entretanto, ainda anteriormente à ocorrência da manifestação, deu-se a finalização do processo de reintegração de posse da área do parque, que teve decisão favorável à prefeitura municipal. Como desdobramento, antes que entrasse em ação a Brigada Militar, incumbida de realizar a desocupação do espaço, os indígenas retiraram voluntariamente as barracas e as mercadorias.

Mesmo perante esse cenário, o evento de "abraço" ao parque foi incentivado pelos organizadores e mantido como evento ativo na internet. Todavia, o protesto não aconteceu e a página na rede social registrou reclamações de indivíduos que se dirigiram ao local, mas não encontraram qualquer mobilização. Pouco tempo depois, a página virtual do evento foi extinta.

Passada uma quinzena da saída espontânea, os Kaingang retornaram ao parque. Fiscais da prefeitura tentaram impedir a reinstalação do camelódromo e acionaram a Brigada Militar. Esta, contudo, reiterou posição anterior de não efetuar qualquer remoção e atuar apenas na prevenção de embates diretos.

Como fruto das negociações entre esses agentes, os indígenas aceitaram montar as estruturas comerciais em frente e não no corredor de ingresso ao parque. Diante de tal quadro, a procuradoria municipal 
informou à imprensa que novamente se reuniria com as autoridades competentes, em busca de encaminhamento definitivo para o caso.

\section{O índio e a cidade}

O relacionamento dos Kaingang e de outras etnias indígenas do Sul do Brasil com as cidades, conforme explicitam Tommasino e Mota (2002), não é contemporâneo, mas sim histórico. O contexto urbano regional erigiu-se, justamente, por sobre territórios indígenas conquistados pelos colonizadores europeus. Igualmente antiga mostrase a relação dos índios com as mercadorias dos brancos. A troca de presentes, como meio de construir relações sociais entre parentes, amigos e estrangeiros, figura como componente fundamental da cultura indígena, que muito logo foi percebido e abraçado enquanto ferramenta da empreitada colonial.

Desse modo, explicam os autores, é praticamente impossível aos índios viverem hoje sem conexão com as cidades e seus elementos. No espaço urbano, eles buscam constantemente ampliar meios de sobrevivência, seja comerciando, estudando, indo ao médico ou fazendo articulações políticas, de maneira que vêm incrementando, ao longo do tempo, o conhecimento e a agência sobre o universo dos brancos. Isso é imprescindível porque suas aldeias atuais, mesmo que demarcadas, são retalhos se comparadas aos territórios originais, onde detinham total independência. Contudo, os indígenas almejam “... usufruir de todos os bens materiais e sociais da modernidade, sem terem de abdicar do direito de serem eles mesmos, preservando sua lógica social e cosmologia" (TOMMASINO e MOTA, 2002, p. 22).

Esse estado de coisas vem de encontro à análise realizada por Nunes (2010): o autor demonstra que, a partir dos anos 2000, houve na antropologia brasileira uma retomada da produção de etnografias sobre a vida indígena em diversos municípios do Brasil, as quais se somaram a trabalhos pioneiros da disciplina datados dos anos 80 , em grande parte feitos ou orientados por Roberto Cardoso de Oliveira.

Uma pesquisa recente é a realizada por Magnani (2013) entre indígenas que residem em Manaus (AM) e arredores. Segundo o 
antropólogo, a abordagem etnográfica tem o potencial de superar retratos clichês de "periferização" dos indígenas em contextos urbanos, ao evidenciar que, a despeito de dificuldades socioeconômicas, eles constroem "redes de sociabilidade" e "trajetos em busca de instituições, alianças e estratégias", de modo a assegurar um "modo de vida diferenciado", com repercussões sobre a dinâmica citadina como um todo.

Não obstante, fora do meio acadêmico, as discussões públicas sobre indígenas em cidades continuam permeadas, como assinala Nunes (2010), pela "questão das essências", espelho direto da dicotomia ontológica "altamente ocidental e ocidentalizante", que aparta a natureza da cultura, objeto de grande crítica antropológica contemporânea ${ }^{13}$.

Tal ótica resulta na desconsideração de acontecimentos históricos, bem do "regime de subjetivação" e do "modelo de socialidade" relativos aos grupos indígenas em muitos dos casos de conflitos vivenciados por eles em áreas urbanas. Como alerta Nunes (2010, p.12), “... estamos falando de populações cuja forma de pensar é muito distinta da nossa; e não poderíamos supor que os índios passassem a pensar com o nosso próprio esquema cognitivo-categorial apenas por que se apropriam de nossas coisas".

No confronto objeto deste artigo, a referida essencialização revela-se patente. Em Viçoso, o discurso tornado público pelas autoridades municipais, pelas entidades empresariais ou pela mídia afirma nutrir respeito pela cultura kaingang, mas tal apreço tem como medida o que Ramos (1998) denomina de "índio hiper-real". A autora emprega uma noção baudrillardiana para explicar tal figura: trata-se de um "simulacro", no qual o indígena surge como um "... clone feito à imagem daquilo que os ocidentais [leia-se, brancos] gostariam que ele fosse" (p. 277, livre tradução).

Em situações de disputa, o "índio hiper-real" costuma oscilar entre os status de "índio-mártir" e de "índio-vendido", conforme os interesses em jogo. O simulacro, em qualquer uma das versões, tudo considera menos a "experiência vivida" dos povos indígenas. Devido ao protagonismo alcançado por estes últimos na contemporaneidade, por

\footnotetext{
${ }^{13}$ Neste âmbito, trabalho tido por ícone é o de Latour (1994).
} 
intermédio de lutas sucessivas, tal imagem genérica, de um lado, tem experimentado situações de ruína, dada sua artificialidade; mas, por outro, detém força residual, tendo em vista situar-se aos brancos como uma ferramenta simplificadora sempre à mão, para ler apressada e parcialmente uma realidade complexa (RAMOS, 1998).

Desse modo, o "índio hiper-real" aspirado em Viçoso é o Kaingang que vive da venda do seu artesanato. Como os Kaingang que realizam atividades comerciais no município não agem em consonância com tal imagem, uma série de denominações e posturas associadas ao "índiovendido" Ihes é imputada. Assim, o discurso público midiatizado classifica-os como pseudoindígenas, que ofertam produtos impuros, depreciadores da cultura típica dos índios. Sob essa leitura, tais cidadãos, ao se ampararem em uma legislação especial, teriam adentrado a cidade de forma petulante, desrespeitosa do arranjo turístico, aproveitadora da prosperidade viçosense e criadora de transtornos comunitários ${ }^{14}$.

Por essa via, o poder público busca reforçar a prerrogativa de regulação do comércio local expressa no código de posturas do município. O arcabouço legal relativo à singularidade dos povos indígenas, por seu turno, não surge visualizado como decorrente do assolamento por eles secularmente experimentado. Uma devastação que, a despeito da violência, não conseguiu extirpar uma maneira particular de viver, expressa nas lutas indígenas cotidianas, como também em diversos estudos etnográficos ${ }^{15}$, conduzidos hoje não apenas por antropólogos brancos, mas também índios. Tais etnógrafos nativos pautam-se pela percepção de que o ferramental da ciência pode atuar como mais um aliado das causas indígenas.

No contexto em análise, o simulacro de "índio-mártir", por sua vez, aparece com evidência menor. $O$ excerto a seguir, retirado de um artigo de opinião assinado em um jornal local por um professor da comunidade, é ilustrativo nesse sentido:

Esperamos que os turistas que forem conhecer 0

\footnotetext{
${ }^{14}$ A síntese do discurso público midiatizado acerca do comércio efetuado pelos Kaingang em Viçoso teve como fonte conteúdo de jornais locais, de documentação oficial, bem como de minhas observações e interlocuções.

${ }^{15}$ Nesse sentido, cf. apanhado de Nunes (2010) e, especificamente sobre os Kaingang, cf. Freitas (2006).
} 
[parque turístico] não pensem que os [viçosenses] perderam o capricho de recebê-los com elegância e carinho. A lamentável favela em que se transforma com frequência, depois que o comércio indígena nele se instalou, é retrato do nosso país, onde o bom senso e a caridade ainda não encontraram lugar.

Constata-se que, embora bem-intencionada, a abordagem do artigo não abandona o terreno da interpretação equívoca.

\section{Dos camelôs e da pirataria}

O cenário de favelização referido no extrato midiático antes citado conecta-se não só à presença de um indígena considerado, de um ponto de vista lugar-comum, como empobrecido material e culturalmente. Vincula-se também à existência, no quadro em foco, de outros elementos pejorativamente entendidos nos contextos citadinos atuais: os vendedores ambulantes e seus produtos associados à pirataria.

O fato de os indígenas se organizarem hoje em um camelódromo em Viçoso e venderem ali artigos ditos de procedência asiática os inclui em um panorama de comércio popular de rua, o qual, segundo Pinheiro-Machado (2013a e 2013b), abrange expressivos contingentes populacionais brasileiros e expressa os profundos e diversificados desníveis estruturais do país. A autora explica que as políticas urbanas têm operado a partir de uma negação desse quadro socioeconômico mais amplo e enquadrado os camelôs como problemas em si mesmos, associados à "sujeira" e à "desordem"; portanto, cabíveis de eliminação via intervenções "higienistas", que não cessam de ocorrer nas cidades do Brasil 16 .

$\mathrm{Na}$ década de 80, vem reforçar essa espécie de medida a proeminência das noções de falsificação e de pirataria na regulação do comércio internacional, tendo em vista a concorrência desencadeada pela pulsante economia da China. Produtos oriundos do país asiático, adquiridos via Paraguai, passaram a abundar nos camelódromos

\footnotetext{
${ }^{16}$ Como exemplo, cf. Frúgoli Jr. (2000), que trata sobre o conflituoso processo de remoção dos camelôs do centro da maior metrópole brasileira, a cidade de São Paulo.
} 
JULIANE BAZZO - UMA IDENTIDADE MUNICIPAL DESAFIADA...

brasileiros que, a partir de então, tornaram-se conectados mais fortemente à ilegalidade e sujeitos a arbitrariedades fiscalizatórias (PINHEIRO-MACHADO, $2013 \mathrm{a}$ e $2013 \mathrm{~b}$ ).

A trajetória dos camelôs no país é entendida pela estudiosa como uma repercussão da "globalização popular", expressão apropriada de Gustavo L. Ribeiro (2007). Expõe ela que nesse movimento “... classes desfavorecidas passaram a atuar como atores ativos dos fluxos globais, distribuindo bens baratos e mudando a cara do consumo popular brasileiro" (PINHEIRO-MACHADO, $2013 \mathrm{a}$, p. 102).

O extenso trabalho de pesquisa de Pinheiro-Machado - que, durante quase uma década, buscou mapear etnograficamente o circuito de mercadorias entre os camelôs de Porto Alegre (RS), os intermediários no Paraguai e os fabricantes na China - atesta que "[m]ercados só existem porque há demanda social" (PINHEIRO-MACHADO, $2013 a$, p. 101), com necessidade de ser compreendida contextualmente. Somente dessa maneira se podem clarificar as contingências, as necessidades e também os interesses dos atores em confronto nesses contextos.

$\mathrm{Na}$ disputa abordada neste artigo, há por parte dos oponentes dos indígenas uma resistência em visualizar tal demanda social, seja aquela de parte dos Kaingang que, dada sua trajetória sócio-histórica, utilizam o comércio de rua como fonte de geração de renda, seja aquela oriunda dos turistas, que passaram a lotar o camelódromo no parque turístico e a adquirir produtos. Nas observações etnográficas realizadas no parque, não se perceberam, entre a massa de visitantes, restrições quanto aos indígenas e aos produtos que eles ofertavam. Pelo contrário, havia empatia comercial, posto que sem ela o intercâmbio seria inviável ${ }^{17}$.

Tal constatação conduz a outras fronteiras da conformação identitária da cidade, assunto do tópico a seguir.

\footnotetext{
17 A fim de conferir respaldo a tal percepção, consultei o TripAdvisor (www.tripadvisor.com.br), destacado site de viagens, por meio do qual os turistas podem avaliar locais específicos de cidades visitadas. Na página reservada nesse portal ao citado parque turístico de Viçoso, a grande maioria das apreciações (4.834 de 5.445, até outubro de 2014) classificava o parque como excelente ou muito bom. Dentre as avaliações tipificadas como ruim ou horrível (um total de 54), oito faziam referência negativa ao camelódromo ou ao comércio excessivo de uma forma geral. A maior parte das queixas concentrava-se no baixo volume de atrativos locais e nos altos preços praticados, especialmente dos passeios temáticos e das opções de alimentação existentes.
} 


\section{Outros contrastes, outros embates}

O comércio kaingang não constitui elemento isolado de contraste no processo de elaboração da identidade emblemática de Viçoso como cidade de feitio europeu. Há outros geradores de outras tensões, ocultamentos ou embates. Nesse sentido, importa ressaltar a sombra lançada não apenas sobre o índio, mas também sobre o português e o negro na versão hegemônica da história local.

Um exemplo disso aparece em uma crônica urbana, disponível em obra do acervo da biblioteca da cidade: nesse texto, um historiador nativo faz um apelo à comunidade pelo resgate da memória de um desbravador local de ascendência lusa, presente no território muito antes da chegada de alemães e italianos. Esse explorador pioneiro foi quem primeiro conseguiu registrar oficialmente as terras onde hoje situa-se Viçoso, depois sucessivamente vendidas a particulares ou doadas à municipalidade. Tal panorama sucedeu-se em meio aos já referidos confrontos entre bugreiros e indígenas nessa região.

A reinauguração de uma praça na cidade em homenagem aos imigrantes europeus, no ano de 2012, evento este descrito em tópico anterior, reflete o conteúdo da convocatória do historiador, que figurou como apoiador da remodelação. O novo espaço público, além de edificações de estilo alemão e italiano, incluiu um espaço de arquitetura açoriana, que permanece, porém, sem uso divulgado, ao contrário dos outros prédios.

Ainda mais turva que a dos portugueses é a trajetória dos negros na composição populacional local. O entendimento corrente é de que, na atualidade, existem numericamente poucos afrodescendentes como moradores na cidade e, por conseguinte, esse quadro atestaria uma contribuição negra diminuta para a história municipal. Todavia, um documento não publicado, resultado de pesquisa de outro historiador local, dá detalhes sobre a existência de quilombos na região, cujas terras foram sucessivamente apropriadas por portugueses e alemães. $O$ estudo relata que chegou a haver em Viçoso uma vila denominada por "africana", onde viveram afrodescendentes por certo tempo.

A opacidade dos elementos indígena, negro e português na identidade emblemática de Viçoso torna-se também evidente no 
contraste estabelecido com uma cidade vizinha, distante poucos quilômetros, a qual chamarei ficticiamente de Florido. As comparações entre as duas localidades encontram-se documentadas historicamente, como também são conteúdo presente nas falas cotidianas dos residentes de ambas. Da parte de Viçoso, há o esforço em destacar o maior glamour e prosperidade da cidade em relação a Florido, que também tem o turismo como atividade econômica central. Dados a um só tempo históricos e etnográficos explicam por quê.

A rivalidade entre os dois municípios data da independência de Florido, nos anos 20, do, à época, distrito de Viçoso. A partir de então, o nascente empresariado florense desonerou-se de impostos cobrados pelo antigo distrito e pôde empregar a verba disponível para alavancar seus negócios. Além disso, uma linha de trem, que antes chegava até Viçoso, foi estendida a Florido, de modo que os visitantes passaram também a abraçar esta última enquanto destino. Ambos os municípios, contudo, experimentariam um declínio do fluxo de viajantes a partir da década de 50 , com a emergência de infraestrutura turística no litoral gaúcho.

Tal momento de decadência conduziu as duas cidades a remodelar arranjos turísticos. Nesse contexto é que se inicia em Viçoso a construção de uma série de empreendimentos e a criação de um calendário de eventos que abraçam um estilo europeu como forma de resgatar o movimento de visitantes. Dentre as obras efetuadas, esteve a do parque turístico onde o camelódromo indígena veio a se instalar. A estratégia deu certo e conquistou não apenas os viajantes, mas também uma nova população residente, que se estabelece em Viçoso atraída pela expressividade dos negócios turísticos e pela qualidade de vida local.

Contudo, os empreendedores viçosenses, embora necessitem de mão de obra externa à cidade, passaram a demonstrar uma inquietude clara até os dias atuais em relação ao inchaço populacional. Do ponto de vista nativo, se de um lado o trabalhador de fora concentra vantagens aos empreendedores locais, como a ausência de laços familiares que racionaliza contratos profissionais, por outro traz consigo uma forma de vida outra, entendida como ameaçadora dos sucessos alcançados pela boa "mistura" de etnias no que tange ao ordenamento municipal. 
Nesse sentido, surge uma inevitável comparação com Florido: os viçosenses costumam mencionar que a prosperidade mais ampla do município vizinho teria encontrado como impedimento uma "mistura" não satisfatória, que resultou nos "pelos duros", termo que aponta para a miscigenação de indígenas, portugueses e negros.

\section{De revezes contemporâneos}

A análise etnográfica mostra-se ainda reveladora de conflitos atuais no interior da própria comunidade viçosense que impactam na modelação identitária da cidade. A instalação de empreendimentos turísticos de grande porte, por exemplo, divide opiniões dos habitantes: há grupos que os visualizam como inevitáveis e imprescindíveis ao contínuo progresso, enquanto outros os entendem como prejudicais, pois incham a cidade em demasia e, dado seu caráter massificado, não valorizam a cultura da região.

A mídia local vem expressando essas visões contraditórias. Há, por exemplo, uma preocupação constante acerca de medidas para conter os congestionamentos de trânsito nos feriados, mas existe também entusiasmo em tratar da expansão turística do município, que aumenta seu número de parques temáticos, cuja inspiração vem dos complexos norte-americanos da Disneylândia.

Em meio a tais tensões, o artesanato local ocupa posição representativa. A despeito de um prestígio outrora experimentado, há hoje uma percepção comunitária de decadência da atividade artesanal. Isso em virtude do ingresso massivo de suvenires e outros objetos industrializados no comércio citadino, de modo que artesãos e técnicas tradicionais passaram a ocupar um segundo plano. Nos anos recentes, pode-se constatar a presença de pontos comerciais do artesanato local em áreas citadinas mais periféricas que centrais, conforme descrito neste artigo, de forma articulada aos percursos indígenas pelo município.

Não obstante, há uma espécie de concordância entre empresários e artesãos acerca da necessidade de combate aos vendedores ambulantes, uma discussão que, na atualidade, vem estampando 
páginas dos jornais locais. Assim como se verificou no caso kaingang, à medida que o movimento turístico aos eventos de Viçoso cresceu, aumentou o número de indivíduos interessados em realizar comércio de rua. Conforme exposto, o código de posturas municipal é a lei que confere à prefeitura a precedência de ordenar esse tipo de atividade. Sendo assim, o poder público tem conferido autorizações nesse sentido, mediante o pagamento de taxas. Porém, registra-se também a presença de atuação informal, alvo de fiscalização.

Nesse contexto, ocorre atualmente um movimento do empresariado em prol da inviabilização de qualquer espécie de comercialização itinerante, no mesmo momento em que se encontra em rediscussão, pela instância legislativa local, o código de posturas, para fins de atualizações. Declararam recentemente à imprensa os representantes de entidades que reúnem proprietários de lojas, bares e restaurantes:

Temos um comércio de qualidade que possui cuidado com a fachada, a decoração e a disposição interna de seus produtos, paga impostos, emite nota fiscal e aí acaba perdendo clientes para esses que vêm, em épocas de grande movimento, instalam-se nas ruas, não pagam impostos, não geram renda e nem emprego. Precisamos fazer algo para valorizar o empresário, o comerciante. Devemos nos questionar o que queremos para [Viçoso] e mediante isso trabalhar na busca de resultados.

Para finalizar essa análise, faz-se necessário considerar um último elemento importante para pensar a identidade emblemática viçosense: o turista. Sob a ótica nativa, esse ator não é unívoco, pois, a depender de seu perfil, tanto reforça quanto destoa da constituição identitária hegemônica. Nos últimos anos, registra-se uma mobilização citadina, constatada no debate midiático e em falas cotidianas, de busca por um turista "qualificado", em detrimento daquele que, geralmente, vem a Viçoso em ônibus de excursão e consome menos que o esperado em hospedagem, alimentação e compras.

Dessa forma, o turista almejado é aquele que, ao mesmo tempo, tem potencial de compra e se afina ao ambiente imaginado como europeizado, organizado e refinado. Trata-se de um contorno que ecoa 
a caracterização dos primeiros turistas do município, membros de elites que detinham poder aquisitivo para passar meses de férias inteiros na região serrana. Mas nem sempre o visitante aspirado é aquele que, em quantidade, encontra-se na rota turística.

Um levantamento do Ministério do Turismo (ca 2005) buscou traçar um perfil do então emergente mercado de viagens movimentado por classes consideradas de baixa renda no país ( $C$ e $D$ ), cenário que indica repercutir efeitos de uma série de políticas de inclusão social iniciadas no governo Lula, a partir de 2003. Nesse estudo, Viçoso desponta como um dos destinos especialmente visados por esse público. Atesta tal demanda a criação, em 2013, de um local exclusivo para estacionamento de ônibus de excursão na cidade, numa tentativa de melhor ordenar o trânsito em períodos de pico da atividade turística.

A despeito do estabelecimento desse espaço, a mídia local atualmente repercute que, do ponto de vista do empresariado, o excursionista não é o turista ideal. Declarou o presidente de uma entidade representativa: "Em regiões mais tranquilas, os visitantes podem investir um ticket médio maior, com diárias de hotéis mais caras e restaurantes mais refinados. (...) Cidade lotada não é sinônimo de economia alta girando".

Os turistas, por sua vez, embora elementos transitórios, não estão completamente passivos a tal cenário. Uma intervenção interessante nesse âmbito foi a reclamação, feita em 2013 por um visitante, acerca da ausência de preços das mercadorias em vitrines de lojas de Florido e região, que, sem dúvida, compreende Viçoso. A queixa tornou-se um inquérito civil, que desencadeou notificações a lojistas, para que se adequassem aos direitos de informação do consumidor.

\section{Considerações finais}

Este artigo buscou refletir sobre a concepção de Viçoso enquanto cidade de feição emblematicamente europeia, com base nas noções sobre identidade de Oliven (2011) e Duarte (1988). Tal análise se deu a partir da problematização do conflito corporificado pelo comércio de produtos industrializados por indígenas Kaingang no município, 
instalados em um camelódromo em um destacado parque turístico.

A identidade emblemática viçosense encontra seu cerne na ideia de uma mescla étnica bem-sucedida, propiciada pela colonização alemã e italiana. $\mathrm{O}$ ethos herdado desses imigrantes teria operado enquanto responsável pela fundação, ordenação e prosperidade do município, que hoje possui expressiva atividade turística e bons índices de qualidade de vida. A discussão aqui empreendida procurou assinalar em detrimento do que e de quem tal identidade é cristalizada e divulgada.

A análise demonstrou que os elementos constituintes da identidade representativa de Viçoso estão baseados numa história de imigração real; porém, parcialmente documentada e propagada. Ademais, dentre eles, situam-se recursos estrategicamente criados materializados na arquitetura, no comércio, na gastronomia e no entretenimento citadino - como tentativa de estabelecer uma atmosfera europeia, capaz de refletir um passado imaginado como venturoso, que repercutiria em benesses no tempo presente. Tal ambiente traduz uma narrativa aspirada pelos viçosenses sobre eles mesmos e, concomitantemente, atua na atração de turistas para conhecer uma espécie de recanto europeu no Brasil.

Identidades, como pontua Oliven (2011), não estabelecem "sinais diacríticos" em campos semânticos vazios, mas sempre se constroem em oposição a outras. No caso aqui analisado, o contraste se dá perante elementos tipicamente brasileiros, sejam eles enquadrados como positivos ou negativos no arcabouço sociocultural nacional. Sob essa ótica, a identidade emblemática viçosense tanto rejeita a narrativa de mistura exitosa das três raças quanto aspira passar à parte das mazelas da condição subdesenvolvida do país. Nesse âmbito, emerge uma série de oponentes identitários, de caráter histórico e/ou contemporâneo: indígenas, portugueses, negros, o município vizinho de Florido, os vendedores ambulantes, assim como os turistas das classes C e D.

Parte desses oponentes, por seu turno, reivindica seu direito à cidade, cada qual pautado por uma história particular, que determina também interesses singulares. Nesse processo, desencadeiam-se inevitáveis conflitos. A despeito do foco em questões pragmáticas, como a regulação do exercício comercial, por exemplo, tais embates revelamse, na verdade, batalhas entre uma identidade hegemônica perante 
outras contra-hegemônicas, que colocam à primeira inúmeros desafios de manutenção.

Souza (1994), ao tratar da presença indígena na região onde se situa Viçoso, efetua uma convocatória à comunidade local: "Deixemos a Europa para os europeus e reivindiquemos nossos americanismos". Para finalizar o presente artigo, surge oportuna uma paráfrase do apelo desse autor, lançando mão de termos de Jacobs (2001 [1961]) acerca do contexto urbano: deixemos as "cidades imaginárias perfeitas" e reivindiquemos "cidades reais".

\section{Referências bibliográficas}

ALMEIDA, Alfredo Wagner Berno de. O domínio original: as terras de índio como terras de preto. In: Os quilombolas e a base de lançamento de foguetes de Alcântara. Brasília: Edições Ibama, 2006. p. 87-101. v. 1.

BOHRER, Felipe Rodrigues. Breves considerações sobre os territórios negros urbanos de Porto Alegre na pós-abolição. Iluminuras, Porto Alegre, v. 12, n. 29, p. 121-152, jul./dez. 2011.

CALDEIRA, Teresa Pires do Rio. Enclaves fortificados: erguendo muros e criando uma nova ordem privada; A implosão da vida pública moderna. In: Cidades de muros: crime, segregação e cidadania em São Paulo. São Paulo: Edusp; Editora 34, 2000. p. 257-340.

CERTEAU, Michel de. A invenção do cotidiano: artes de fazer. Petrópolis: Editora Vozes, 1998. v. 1.

DAMATTA, Roberto. Digressão: a fábula das três raças ou o problema do racismo à brasileira. In: Relativizando: uma introdução à antropologia social. Rio de Janeiro: Rocco, 1990. p. 58-87.

DUARTE, Luiz Fernando D. Modernidade e classes trabalhadoras urbanas. In:

Da vida nervosa nas classes trabalhadoras urbanas. Rio de Janeiro: Jorge Zahar Editor, 1988. p. 119-142.

ELIAS, Norbert; SCOTSON, John L. Introdução: ensaio teórico sobre as relações estabelecidos-outsiders. In: Os estabelecidos e os outsiders: sociologia das relações de poder a partir de uma pequena comunidade. Rio de Janeiro: Jorge Zahar Editor, 2000. p. 19-50. 
FREITAS, Ana Elisa de Castro. Mrür Jykre: a cultura do cipó. Territorialidades Kaingang na Bacia do Lago Guaíba, Porto Alegre, Rio Grande do Sul, Brasil. In: KUBO, Rumi Regina et al. (Org.). Atualidades em etnobiologia e etnoecologia. Recife: Nuppea/SBEE, 2006. p. 225-244. v. 3.

FRÚGOLI JR., Heitor. Conflitos e negociações em torno da requalificação do centro de São Paulo: a Associação Viva o Centro. In: Centralidade em São Paulo: trajetórias, conflitos e negociações na metrópole. São Paulo: Cortez/Editora da Universidade de São Paulo, 2000. p. 69-109.

GODOI, Emília Pietrafesa de. O sistema do lugar: história, território e memória no sertão. In: NIEMAYER, Ana Maria de; GODOI, Emília Pietrafesa de (Org.). Além dos territórios: para um diálogo entre a etnologia indígena, os estudos rurais e os estudos urbanos. Campinas: Mercado das Letras, 1998. p. 97-131.

GORDON, Cesar. Economia selvagem: ritual e mercadoria entre os índios XikrinMebêngôkre. São Paulo: ISA/NUTI/UNESP, 2006.

GUIMARÃES, Josué. A ferro e fogo: Tempo de solidão. Rio de Janeiro: José Olympio, 1977. v. 1.

HOLSTON, James. A morte da rua. In: A cidade modernista: uma crítica de Brasília e sua utopia. São Paulo: Companhia das Letras, 1993. p. 109-149.

JACOBS, Jane. Introdução. In: Morte e vida de grandes cidades. São Paulo: Martins Fontes, 2001. p. 1-27.

LATOUR, Bruno. Jamais fomos modernos: ensaio de antropologia simétrica. Rio de Janeiro: Editora 34, 1994.

LEFEBVRE, Henri. Industrialização e urbanização: notas preliminares. In: $\mathbf{O}$ direito à cidade. São Paulo: Centauro, 2001. p. 11-33.

LEITE, Rogerio Proença. Margens do dissenso: espaço, poder e enobrecimento urbano. In: FRÚGOLI JR., Heitor et al. (Org.). As cidades e seus agentes: práticas e representações. Belo Horizonte/São Paulo: Editora PUCMINAS/Edusp, 2006. p. 23-44.

LOW, Setha M. Cultura in the modern city: the microgeographies of gender, class, and generation in the Costa Rican Plaza. Horizontes Antropológicos, Porto Alegre, v. 6, n. 13, p. 31-64, jun. 2000.

MAGNANI, José Guilherme Cantor. Da periferia ao centro, cá e lá: seguindo trajetos, construindo circuitos. Anuário Antropológico/2012, Brasília, v. 38, n. 2, p. 53-72, 2013.

MINISTÉRIO DO TURISMO. Classes C e D: um novo mercado para o turismo brasileiro. Relatório final. Ca 2005. Disponível em: www.turismo.gov.br . Acesso em: out. 2014. 
. Caracterização e dimensionamento do turismo doméstico no Brasil 2010/2011. Relatório Executivo. São Paulo, set. 2012. Disponível em: www.dadosefatos.turismo.gov.br . Acesso em: out. 2014.

NUNES, Eduardo Soares. Aldeias urbanas ou cidades indígenas? Reflexões sobre índios e cidades. Espaço Ameríndio, Porto Alegre, v. 4, n. 1, p. 9-30, jan./jun. 2010.

OLIVEN, Ruben George. A parte e o todo: a diversidade cultural no Brasil-nação. Petrópolis: Vozes, 2011.

PÉTONNET, Colette. Observação flutuante: o exemplo de um cemitério parisiense. Antropolítica, Niterói, n. 25, p. 99-111, 2008.

PINHEIRO-MACHADO, Rosana. Anos de pedra: etnografia de um camelódromo. In: ROCHA, Ana Luiza Carvalho da; ECKERT, Cornelia (Org.). Etnografia de rua: estudos de antropologia urbana. Porto Alegre: Editora da UFRGS, 2013a. p. 94-120.

Pirataria: uma chave para pensar o modelo de desenvolvimento brasileiro e chinês. In: FELDMAN-BIANCO, Bela (Org.). Desafios da antropologia brasileira. Brasília: ABA, 2013b. p. 308-344.

PNUD. Atlas do desenvolvimento humano no Brasil 2013. Disponível em: www.pnud.org.br . Acesso em: jul. 2014.

RAMOS, Alcida Rita. The hyperreal indian. In: Indigenism: ethnic politics in Brazil. Madison: University of Wisconsin Press, 1998. p. 267-283.

RIBEIRO, Gustavo Lins. El sistema mundial no-hegemónico y la globalización popular. Série Antropologia, Brasília, n. 410, 2007.

SOUZA, José Otávio Catafesto de. A presença indígena no quadrante histórico patrulhense. Palestra proferida no V Encontro de Municípios originários de Santo Antônio da Patrulha, 1994.

TOMMASINO, Kimiye; MOTA, Lúcio Tadeu. As cidades e os Kaingang no Paraná. In: 23a REUNIÃO BRASILEIRA DE ANTROPOLOGIA. Anais... Brasília: Associação Brasileira de Antropologia, 2002.

VELHO, Gilberto. Observando o familiar. In: Um antropólogo na cidade: ensaios de antropologia urbana. Rio de Janeiro: Zahar, 2013 [1978]. p. 45-51.

Recebido em: 22/10/2014* Aprovado em: 02/04/2015* Publicado em: 30/06/2015 